\title{
Homogeneidad de los hormigones autocompactantes
}

\section{Self-consolidating concrete homogeneity}

\author{
M. O. Valcuende ${ }^{(*)}$, C. Parra(**) y J. C. Jarque(***)
}

Recepción/Received: 14-XII-05

Aceptación/Accepted: 9-II-07

RESUMEN

En este trabajo se estudia la homogeneidad de los hormigones autocompactantes en piezas hormigonadas verticalmente, determinando su resistencia a la segregación y la uniformidad de su estructura porosa, dado que la pérdida de estabilidad de una mezcla puede conducir a una distribución no uniforme de sus propiedades. Para ello se han fabricado dos tipos de hormigones, uno autocompactante y otro tradicional vibrado, con diferentes relaciones a/c y distintos tipos de cemento. Los resultados ponen de manifiesto que los hormigones autocompactantes presentan una buena resistencia a la segregación, aunque algo menor que la registrada en los hormigones tradicionales. A pesar de ello, su estructura porosa tiende a ser ligeramente más uniforme, debido probablemente a un menor sangrado. Asimismo, presentan una mayor densidad aparente, una menor porosidad y un menor tamaño medio de poro, lo que les confiere mejores prestaciones frente a la penetración de agua bajo presión. Ahora bien, para diámetros de poro superiores aproximadamente a 0,5 $\mu \mathrm{m}$, la distribución de tamaños de poro es similar a la de los hormigones tradicionales, dando lugar a una absorción también similar.

Palabras clave: hormigón autocompactante, segregación, porosidad, absorción, permeabilidad.
SUMMARY

Concrete instability may lead to the non-uniform distribution of its properties. The homogeneity of self-consolidating concrete in vertically cast members was therefore explored in this study, analyzing both resistance to segregation and pore structure uniformity. To this end, two series of concretes were prepared, self-consolidating and traditional vibrated materials, with different $\mathrm{w} / \mathrm{c}$ ratios and types of cement. The results showed that selfconsolidating concretes exhibit high resistance to segregation, albeit slightly lower than found in the traditional mixtures. The pore structure in the former, however, tended to be slightly more uniform, probably as a result of less intense bleeding. Such concretes are also characterized by greater bulk density, lower porosity and smaIler mean pore size, which translates into a higher resistance to pressurized water. For pore diameters of over about $0.5 \mu \mathrm{m}$, however, the pore size distribution was found to be similar to the distribution in traditional concretes, with similar absorption rates.

Keywords: self-consolidating concrete, segregation, porosity, absorption, permeability.

(*) Universidad Politécnica de Valencia (Valencia, España).

(**) Universidad Politécnica de Cartagena (Cartagena, España).

(***) Instituto de Tecnología Cerámica. Universidad Jaime I de Castellón (Castellón, España). 


\section{INTRODUCCIÓN}

El hormigón autocompactante (HAC) puede definirse como aquel que es capaz de fluir en el interior del encofrado, pasando entre las armaduras y consolidándose únicamente bajo la acción de su propio peso, sin necesidad de compactación y sin presentar segregación o exudación.

Una de las dificultades que plantea la fabricación de este tipo de hormigones es la estabilidad de la mezcla, pues a medida que aumenta la fluidez del material, su resistencia a la segregación disminuye, y puede dar lugar durante el vertido a bloqueos de los áridos al pasar por zonas congestionadas de armaduras $y$, una vez endurecido, a defectos superficiales y a una distribución no uniforme de sus propiedades físicas y mecánicas.

La segregación, que puede producirse durante el transporte y vertido (segregación dinámica) o tras la puesta en obra (segregación estática), es un fenómeno que diversos autores han intentado explicar mediante modelos matemáticos. Algunos de estos modelos permiten determinar el tamaño máximo del árido que puede permanecer en suspensión en una mezcla. Según Saak et al. (1), Jossic y Magnin (2) o Beris et al. (3), dicho tamaño depende de la tensión de corte inicial del hormigón (fluidez) y de las densidades de la pasta y los áridos. Lógicamente, cuanto menor es el tamaño de las partículas, menor es el riesgo de segregación.

Aunque las expresiones de Jossic y Magnin o de Beris et al. proporcionan resultados aceptables (4), el fenómeno de la segregación es mucho más complejo, pues no depende sólo de la fluidez del material, sino que intervienen otros factores, tales como la viscosidad plástica, la tixotropia o la granulometría, que interfieren unos sobre otros (5). Así, por ejemplo, los áridos más pequeños, que están en suspensión, forman una malla que evita parcialmente el descenso de los más grandes (efecto malla). En el caso de granulometrías discontinuas, ante la falta de tamaños de árido intermedios que retengan a los más grandes, es necesario utilizar mezclas más viscosas. Igualmente, si se fabrican HAC con una tensión de corte inicial muy baja, su viscosidad debe ser elevada, y viceversa.

Por otra parte, también se ha observado que la composición de los materiales influye bastante en la estabilidad de la mezcla, comportándose mejor los superplastificantes compuestos a base de policarboxilatos que los compuestos a base naftalenos (6). Además, un factor decisivo a tener en cuenta es la relación volumétrica agua/finos, debiendo ésta aproximarse a los valores propuestos por Okamura (7).

Para aumentar la viscosidad de la pasta, existen básicamente dos opciones: incrementar el contenido de finos

\section{INTRODUCTION}

Self-consolidating concrete (SCC) may be defined to be concrete with sufficient flowability inside formwork to surround the reinforcing bars and consolidate under its own weight, with no need for vibration and with no segregation or bleeding.

One of the difficulties encountered when making this type of concrete is possible mixture instability, for the likelihood of segregation grows with fluidity. Segregated aggregate, in turn, may get caught in densely reinforced areas, causing surface flaws and an uneven distribution of physical and mechanical properties in the hardened concrete.

Many authors have tried to develop mathematical models to explain segregation, which may take place during (dynamic segregation) or after (static segregation) transport and pouring. Some of these models can be used to determine the maximum aggregate size that can be held in suspension in a mixture. According to Saak et al. (1), Jossic and Magnin (2) and Beris et al. (3), that size depends on the initial shear stress of the concrete (fluidity) and paste and aggregate density. The smaller the particle size, naturally, the lower is the risk of segretation.

Although the expressions proposed by Jossic and Magnin and Beris et al. yield acceptable results (4), segregation is a much more complex phenomenon than described in their models, and depends not on fluidity alone, but on other factors such as plastic viscosity, thixotropy and particle size distribution (5). Thus, for example, the finer aggregate, which is in suspension, forms a lattice that partially hinders the descent of the larger particles (lattice effect). In gap grading, the lack of intermediate aggregate sizes to retain these larger particles entails the need to use more viscous mixtures. Similarly, when the initial shear stress in an SCC is low, its viscosity must be high and vice-versa.

Material composition has also been observed to affect mixture stability, with poilycarboxylate-based superplasticizers exhibiting better behaviour in this regard than their naphthalene-based counterparts (6). The volumetric ratio of fines to water is also a decisive factor and should be within or near the values proposed by Okamura (7).

There are essentially two ways to increase paste viscosity: increasing the fines content by adding cement or 
mediante la incorporación de cemento o adiciones, tales como cenizas volantes, escorias de alto horno o filler calizo, o introducir aditivos cohesionantes, que están compuestos por polímeros formados por largas cadenas de moléculas capaces de absorber y fijar parte del agua libre existente. Lamentablemente, hoy por hoy los HAC son muy sensibles a pequeñas variaciones en el contenido de agua de la mezcla, pues pequeños cambios de humedad de los áridos, inferiores incluso al 1,5\%, pueden alterar suficientemente la viscosidad de la mezcla, haciendo que ésta pierda sus propiedades de fluidez o que, por el contrario, pase a segregarse (7).

A pesar de que los finos también son capaces de retener una importante cantidad de agua libre sobre su superficie, en diversas investigaciones se ha puesto de manifiesto que mediante el empleo de aditivos cohesionantes se obtienen hormigones más estables frente a las variaciones de agua de la mezcla que los fabricados sólo con finos $(7,8)$. Esta mayor estabilidad no sólo se traduce en una distribución más uniforme de sus propiedades mecánicas, sino que también parece influir en la calidad de las interfaces árido-pasta y acero-pasta, habiéndose observado por microscopía electrónica una estructura más densa de la zona de transición (8).

En los últimos años son numerosas las investigaciones que se han emprendido con el fin de desarrollar ensayos que permitan determinar de forma sencilla y fiable la resistencia a la segregación de un HAC antes de su puesta en obra. Sin embargo, los resultados alcanzados no han permitido todavía establecer ensayos normalizados al respecto (9).

Los métodos que se utilizan para determinar la uniformidad de la mezcla pueden clasificarse en dos grandes grupos: los que se realizan en hormigón fresco y los que se realizan en hormigón endurecido. Dentro del primer grupo hay muchos tipos $(6,10,11,12,13)$, algunos de los cuales se basan en establecer la resistencia a la segregación en función de las propiedades reológicas del material. No obstante, los resultados que se obtienen con estos últimos son algo contradictorios, alcanzándose buenas correlaciones en unos casos (14) y malas en otros $(7,15,16)$. Ante la necesidad de evaluar con criterios objetivos la resistencia a la segregación de un $\mathrm{HAC}$, uno de los planteamientos más comúnmente establecidos es estudiar la variación de árido grueso con la altura. Para ello se han ideado numerosos ensayos, donde las diferencias más importantes entre unos y otros estriban fundamentalmente en la forma y dimensiones de los moldes empleados $(7,12,14,16,17,18)$.

Por lo que respecta a los ensayos en hormigón endurecido, lo más habitual es estudiar la variación de las propiedades mecánicas o físicas del material $(8,19,20,21,22)$, o analizar la posición de los áridos gruesos, ya sea viendo additions such as fly ash, blast furnace slag or limestone filler; or introducing viscosity-enhancing admixtures consisting of polymers made up of long chains of molecules that can absorb and fix part of the free water content. Unfortunately, today's SCCS are still highly sensitive to slight variations in water content. Minor changes in aggregate moisture, even smaller than $1.5 \%$, can alter mixture viscosity considerably, reducing fluidity and raising the risk of segregation (7).

Although fines may also retain a fair amount of free water on their surface, several studies have shown that concretes made with viscosity-enhancing admixtures are more stable in terms of variations in water content than mixtures made with fines only $(7,8)$. Greater stability not only leads to a more uniform distribution of the mechanical properties of the material, but also seems to enhance the quality of the aggregate-paste and steel-paste interfaces. Electron microscopic studies have shown the structure of these transition zones to be denser in more stable compounds (8).

In recent years, many researchers have sought a simple and reliable method for determining the ability of SCC to resist segregation prior to casting. Nonetheless, no standardized tests have been forthcoming to date (9).

The methods used to determine mixture uniformity can be classified into two main groups: tests on fresh and tests on hardened concrete. The first group comprises many different types of procedures $(6,10,11,12,13)$, some of which establish the resistance to segregation on the basis of concrete rheology. These tests may yield contradictory results, however, with good correlations in some cases (14) and poor in others $(7,15,16)$. One of the most common approaches to the objective evaluation of SCC resistance to segregation is to study the variation in coarse aggregate content by column height. Any number of tests have been designed in this regard, the chief differences between them lying in the shape and dimensions of the moulds used $(7,12,14,16,17,18)$.

As a general rule, tests on hardened concrete analyze variations in the mechanical or physical properties of the material $(8,19,20,21,22)$ or the position of the coarse aggregate, either by observing its distribution throughout 
su distribución a lo largo de la pieza (23), o simplemente midiendo la distancia a la cara superior de hormigonado de los situados más cerca de ella $(12,24)$. En ocasiones también se ha intentado abordar el problema de la estabilidad a través de la simple inspección visual. No obstante, este método tiene un campo de aplicación muy limitado. De hecho, en los ensayos realizados por Lowke et al. (7) la pérdida de uniformidad sólo es apreciable a simple vista cuando las diferencias de contenido de árido grueso entre las zonas superior e inferior de probetas de $450 \mathrm{~mm}$ de altura son muy grandes, del orden del $55 \%$, pero no cuando son pequeñas, del orden del $15 \%$.

De acuerdo con los escasos trabajos realizados hasta la fecha para determinar la resistencia a la segregación de los HAC, los resultados obtenidos por Khayat et al. $(19,20)$, por Gibbs y Zhu (25) y por Zhu et al. (21), donde se analizan algunas de las propiedades mecánicas y físicas del material en piezas de 1,5 y $3 \mathrm{~m}$ de altura, parecen indicar que la estabilidad de las mezclas es similar, o incluso algo mejor, a la de los hormigones convencionales. Según Hoffmann y Leemann (22), no existen diferencias significativas entre ambos materiales, si bien los HAC tienden a presentar una mayor homogeneidad cuando se trabaja con piezas de geometría compleja o fuertemente armada, donde no es posible garantizar una correcta compactación de los hormigones convencionales, siendo, por tanto, las condiciones de ejecución un factor importante a tener en cuenta.

\section{OBJETIVOS Y PLAN EXPERIMENTAL}

El objetivo que se plantea en este trabajo es estudiar la homogeneidad de los HAC en piezas hormigonadas verticalmente, determinando no sólo su resistencia a la segregación, sino también la uniformidad de su estructura porosa, dado que la pérdida de estabilidad de una mezcla puede conducir a una distribución no uniforme de sus propiedades físicas y mecánicas.

De acuerdo con este objetivo, el plan experimental ha consistido en la fabricación de dos tipos de hormigones: uno autocompactante $(A)$ y otro tradicional $(T)$, actuando este último como hormigón de referencia. Con el fin de cubrir el rango habitual de resistencias utilizadas en edificación, para cada tipo de hormigón se han diseñado cuatro dosificaciones distintas, empleándose para ello 3 relaciones a/c $(0,65$, $0,55$ y 0,45$)$ y dos clases resistentes de cemento Portland con adiciones ( 32,5 y 42,5). En cada amasada se han fabricado diversos tipos de probetas (Figura 1), que se desmoldaron a las 24 horas y se mantuvieron en una cámara de curado a $20^{\circ} \mathrm{C}$ y $\mathrm{HR}$ superior al $95 \%$ hasta alcanzar la edad de 28 días. Para la confección de las probetas de hormigón autocompactante el hormigón se colocó sin compactar, llenándose los moldes de una sola tongada. Las características de cada dosificación están recogidas en la Tabla 1. the column (23) or simply measuring the distance from the upper-most coarse aggregate to the top concrete surface $(12,24)$. The problem of stability has occasionally been broached by simple visual inspection, but the applicability of this method is fairly limited. Indeed, according to tests conducted by Lowke et al. (7), unevenness is only perceptible to the naked eye when the difference in coarse aggregate content between the upper and lower zones of a $450-\mathrm{mm}$ specimen is on the order of $55 \%$, but not when the difference is smaller, at $15 \%$, for instance.

Further to the scant studies conducted to date to determine SCC segregation resistance, the results obtained by Khayat et al. (19, 20), Gibbs and Zhu (25) and Zhu et al. (21), who analyzed some of the mechanical and physical properties of the material in specimens 1.5 and $3 \mathrm{~m}$ high, these mixtures are as -or even slightly more- stable than conventional concretes. Hoffmann and Leemann (22) found no significant differences between the two materials, although the SCCs tended to exhibit greater homogeneity in complex geometries or densely reinforced specimens, where full consolidation of conventional concretes cannot be guaranteed. Casting conditions are therefore an important factor to bear in mind.

\section{OBJECTIVES AND EXPERIMENTAL}

This purpose of this study was to analyze the homogeneity of SCC in vertically cast members, determining not only resistance to segregation but also pore structure uniformity, on the understanding that mixture instability may lead to the non-uniform distribution of the physical and mechanical properties of concrete.

Consequently, the working plan involved making two types of concrete: a self-consolidating concrete $(A)$ and a traditional concrete $(T)$ used as a control. Four different mixes were designed for each type, using $3 \mathrm{w} / \mathrm{c}$ ratios $(0.65,0.55$ and 0.45$)$ and two strengths of additioned Portland cement (32.5 and 42.5) to cover the standard strength range used in building construction. The different types of specimens made from each batch (Figure 1) were removed from the moulds after 24 hours and cured for 28 days in a moist cabinet at $20^{\circ} \mathrm{C}$ and $\mathrm{RH}$ of over $95 \%$. The SCC moulds were filled in a single lift, without consolidating the concrete. The characteristics of the various mixes are given in Table 1. 
Tabla 1 / Table 1

Dosificación y resistencia a compresión de los hormigones

Mixture proportions and compressive strength of concretes

\begin{tabular}{|c|c|c|c|c|c|c|c|c|c|c|c|}
\hline $\begin{array}{l}\text { Dosificación } \\
\text { Mix }\end{array}$ & $\begin{array}{c}\text { Hormigón } \\
\text { Concrete }\end{array}$ & $\begin{array}{c}\mathbf{f}_{\mathrm{c}} \\
(\mathrm{MPa})\end{array}$ & $\begin{array}{l}a / c \\
w / c\end{array}$ & $\begin{array}{c}\text { Cemento } \\
\text { Cement }\end{array}$ & $\begin{array}{c}\text { Agua }(*) \\
\text { Water } \\
(\mathbf{k g})\end{array}$ & $\begin{array}{c}\text { Cemento } \\
\text { Cement } \\
\left(\mathbf{k g} / \mathrm{m}^{3}\right) \\
\end{array}$ & \begin{tabular}{|c|} 
Aditivo \\
Admixture \\
$\left(\mathbf{k g} / \mathbf{m}^{3}\right)$ \\
\end{tabular} & $\begin{array}{c}\text { Grava } \\
\text { Gravel } \\
\left(\mathbf{k g} / \mathbf{m}^{3}\right) \\
\end{array}$ & $\begin{array}{c}\text { Arena gruesa } \\
\text { Coarse sand } \\
\left(\mathbf{k g} / \mathrm{m}^{3}\right)\end{array}$ & $\begin{array}{c}\text { Arena fina } \\
\text { Fine sand } \\
\left(\mathrm{kg} / \mathrm{m}^{3}\right)\end{array}$ & $\begin{array}{c}\text { Agua / finos } \\
\text { Water / fines } \\
\left(\mathrm{m}^{3} / \mathrm{m}^{3}\right)\end{array}$ \\
\hline 1 & $A-65-32$ & 30.64 & 0.65 & CEM 32.5 & 175.06 & 275 & 4.68 & 824.30 & 223.10 & 892.20 & 1.06 \\
\hline 2 & A-55-32 & 39.49 & 0.55 & CEM 32.5 & 174.64 & 325 & 5.20 & 806.00 & 436.20 & 654.30 & 1.00 \\
\hline 3 & A-55-42 & 48.98 & 0.55 & CEM 42.5 & 174.90 & 325 & 4.88 & 806.00 & 436.20 & 654.30 & 1.00 \\
\hline 4 & A-45-42 & 59.27 & 0.45 & CEM 42.5 & 175.20 & 400 & 6.00 & 777.20 & 630.90 & 420.60 & 0.92 \\
\hline 1 & T-65-32 & 28.73 & 0.65 & CEM 32.5 & 177.21 & 275 & 1.93 & 824.55 & 1115.57 & --- & 1.17 \\
\hline 2 & T-55-32 & 33.07 & 0.55 & CEM 32.5 & 176.93 & 325 & 2.28 & 806.50 & 1091.10 & --- & 1.07 \\
\hline 3 & T-55-42 & 44.19 & 0.55 & CEM 42.5 & 177.45 & 325 & 1.63 & 806.50 & 1091.10 & --- & 1.07 \\
\hline 4 & T-45-42 & 49.62 & 0.45 & CEM 42.5 & 178.40 & 400 & 2.00 & 777.70 & 1052.20 & --- & 0.95 \\
\hline
\end{tabular}

(*) No está incluida el agua que aporta el aditivo / Excluding admixture water.

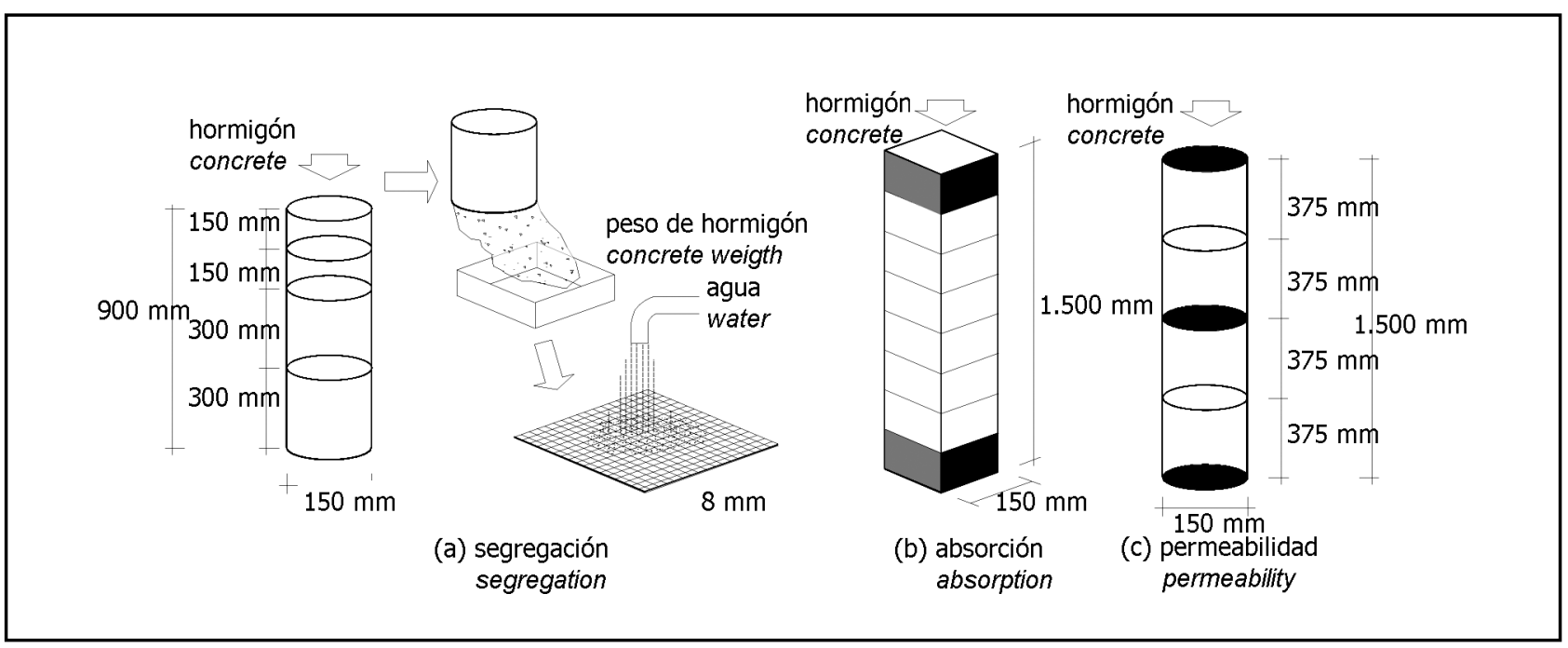

Figura 1. Esquema del ensayo de segregación y de las probetas utilizadas en los ensayos de absorción y permeabilidad.

Figure 1. Segregation test and specimens used in the absorption and permeability tests.

Para la fabricación de los hormigones autocompactantes se han utilizado áridos de machaqueo calizos, empleándose una grava 4/12 y dos tipos de arenas: una gruesa de $0 / 4$, cuya curva granulométrica está dentro del huso definido por la EHE para áridos finos, y otra fina de 0/2, con un contenido de finos $(<0,063 \mathrm{~mm}$ ) muy elevado, del $19,2 \%$, cuya función principal ha sido la de proporcionar el filler necesario para poder conseguir este tipo de hormigones. Por lo que respecta al cemento, la mitad de las dosificaciones se han fabricado con un cemento tipo CEM II / B-M (V-LL) 32,5 N y la otra mitad con un CEM II / B-M (V-LL) 42,5 R. El aditivo utilizado ha sido el Glenium C303 SCC, ajustándose su dosificación hasta alcanzar en el hormigón las características adecuadas de fluidez y viscosidad. A tal fin se hicieron los ensayos de slump-flow y $V$-funnel, cuyos resultados están recogidos
The self-consolidating concrete was made with crushed lime, 4/12 gravel aggregate and two types of sand: a coarser variety, 0/4, whose grading curve lies within the limits defined by EHE for fine aggregates, and a finer type, 0/2, with a very high - 19.2\%- fines content (particle size $<0.063 \mathrm{~mm}$ ), used primarily as the filler required to obtain this type of concrete. Half of the mixes were made with cement type CEM II / B-M (V-LL) 32.5 $N$ and the other half with CEM II / B-M (V-LL) $42.5 R$. Glenium C303 SCC was used as an admixture in doses adjusted to achieve suitable fluidity and viscosity, based on slump and $V$-funnel testing. The results are given in Table 2. The mixes were designed using the Gettu et al. (26) method, i.e., separately optimizing paste composition and aggregate grading. The paste consisted in cement, limestone filler, water and superplasticizer, 
en la Tabla 2. El procedimiento de dosificación empleado es el propuesto por Gettu et al. (26). Se fundamenta en una optimización por separado de la composición de la pasta y del esqueleto granular del árido. La pasta, en el caso propuesto, está constituida por cemento, filler calizo, agua y superplastificante, mientras que el esqueleto granular se define por la relación óptima entre arena y grava que proporciona la estructura de máxima compacidad en seco y sin compactar.

Tomando como referencia las 4 dosificaciones establecidas para HAC se confeccionaron los correspondientes $\mathrm{HT}$, manteniéndose los mismos tipos y contenidos de cemento y las mismas relaciones agua/cemento y arena/grava. Ahora bien, al no ser recomendable fabricar hormigones convencionales con una cantidad de finos tan grande como la demandada por los HAC, se optó por utilizar sólo arena 0/4, ya que su mezcla con arena $0 / 2$ proporciona un árido con un exceso de finos cuya granulometría ya no se ajusta a las prescripciones que marca la EHE al respecto. Por otro lado, dadas las condiciones de fluidez de los HAC y con el objeto de obtener HT con la misma trabajabilidad para las 4 dosificaciones estudiadas, el contenido de superplastificante, que en este caso fue el Glenium C355, se ajustó hasta conseguir en las distintas mezclas un asiento en el cono de Abrams de $14 \pm 0,5 \mathrm{~cm}$. De acuerdo con los requisitos recogidos en la norma europea EN-12390-2, para la fabricación de las probetas los moldes se llenaron por tongadas, compactándose el hormigón con un vibrador interno de aguja.

Para la determinación de la resistencia a la segregación se ha estudiado la variación con la altura de las partículas de árido más gruesas. Para ello se han fabricado unas probetas cilíndricas de $15 \mathrm{~cm}$ de diámetro y $90 \mathrm{~cm}$ de altura (Figura 1) en las que se ha dejado reposar la mezcla un tiempo prudencial (30 minutos los HT y 45 minutos los HAC). Posteriormente, se dividieron en cuatro partes y se lavó el hormigón, haciéndolo pasar por un tamiz de $8 \mathrm{~mm}$ de luz de malla. El árido retenido se secó en una estufa a $50^{\circ} \mathrm{C}$ durante 24 horas y se pesó, determinándose su concentración en cada una de las zonas estudiadas. Para cada dosificación se han realizado tres amasadas, tomándose como resultado del ensayo la media aritmética de los 3 valores obtenidos.

Por lo que respecta a la porosidad, los ensayos efectuados han sido dos: absorción de agua (norma ASTM C 642-97) y obtención de la profundidad máxima de penetración de agua bajo presión (norma europea EN 12390-8). El primero de ellos se ha realizado en muestras de $0,9 \mathrm{~kg}$ de peso aproximadamente, tomadas de las zonas superior, central e inferior de probetas prismáticas de $15 \mathrm{~cm}$ de lado y $150 \mathrm{~cm}$ de altura. Las medidas de absorción se han establecido desecando previamente whilst aggregate grading was defined by the sand/gravel ratio that afforded the structure the highest uncompacted dry density.

The TCS were prepared with the same types and contents of cement and the same water/cement and sand/gravel ratios as the respective SCCS. Nonetheless, since conventional concrete should not be made with the high proportion of fines needed for SCC, only 0/4 sand was used, for inclusion of 0/2 would have entailed an over-proportion of fines and a grain size distribution that would not have conformed to EHE (Spanish structural concrete standard) requirements. Furthermore, the same workability as attained for the SCCS was obtained for the four TC mixes studied by adjusting the superplasticizer content, in this case Glenium C355, to achieve an Abrams cone slump of $14 \pm 0.5 \mathrm{~cm}$. Specimens were made to European standard EN-12.390-2 requirements, filling moulds in successive lifts and consolidating the concrete with a needle vibrator.

The variations in coarse aggregate content by height were studied to determine the resistance to segregation. Cylindrical specimens measuring $15 \mathrm{~cm}$ in diameter and $90 \mathrm{~cm}$ high were prepared (Figure 1) and let stand for a pre-defined time (30 minutes for TC and 45 for SCC). They were then divided (horizontally) into four sections and the concrete was washed and sieved using an 8-mm mesh. The aggregate retained was weighed after oven drying at $50^{\circ} \mathrm{C}$ for 24 hours to determine its concentration in each of the sections. Three batches were made from each mix and the test result was taken to be the arithmetic mean of the three values obtained.

Two porosity tests were conducted: water absorption (ASTM standard C 642-97) and maximum penetration of pressurized water (European standard EN 12390-8). The former was performed on samples weighing approximately $0.9 \mathrm{~kg}$ taken from the upper, middle and lower zones of prismatic specimens $15 \mathrm{~cm}$ wide and $150 \mathrm{~cm}$ high. Prior to conducting the absorption tests, specimens were dried in an oven at $110^{\circ} \mathrm{C}$ to constant weight and submerged in water, also to constant weight. The second 
las probetas en estufa a $110^{\circ} \mathrm{C}$ hasta peso constante y sumergiéndolas luego en agua hasta alcanzar también peso constante. El segundo tipo de ensayo se ha hecho en probetas cilíndricas de $15 \mathrm{~cm}$ de diámetro y $150 \mathrm{~cm}$ de altura que antes del ensayo se dividieron en cuatro partes iguales (Figura 1). Sobre una de las caras de las piezas resultantes se aplica agua a una presión de $500 \pm$ $50 \mathrm{kPa}$ durante 72 horas. Transcurrido este tiempo las probetas se abren axialmente (ensayo brasileño) y se mide la profundidad de penetración de agua. Tanto en el ensayo de absorción como en el de permeabilidad, para cada dosificación se han realizado 4 amasadas, en cada una de las cuales se han fabricado 2 columnas, tomándose como resultado de cada ensayo la media aritmética de los 8 valores obtenidos.

Paralelamente, con el fin de analizar la estructura porosa del hormigón, se han determinado también las distribuciones de tamaño de poro con un porosímetro de mercurio de la marca Micromeritics, modelo AutoPore III. Para la realización de este ensayo se tomaron muestras de unos $2 \mathrm{~g}$ de peso aproximadamente de las zonas superior e inferior de las probetas prismáticas utilizadas en los ensayos de absorción. Las muestras se secaron previamente en estufa a $110{ }^{\circ} \mathrm{C}$.

\section{RESULTADOS Y DISCUSIÓN}

\subsection{Segregación}

De acuerdo con los trabajos realizados por Bui et al. (12), la resistencia a la segregación de un HAC puede considerarse satisfactoria si la variación de árido grueso a lo largo de la altura, $\mathrm{R}_{\mathrm{v}}$, calculada con la siguiente expresión [1], es inferior al 10\%: test was conducted with cylindrical specimens $15 \mathrm{~cm}$ in diameter and $150 \mathrm{~cm}$ high, divided into four equal parts (Figure 1). One side of the specimens was exposed to pressurized water at $500 \pm 50 \mathrm{kPa}$ for 72 hours. The specimens were then subjected to the tensile splitting (Brazilian) test and the depth of water penetration was measured. Two columns were made from each of the four batches prepared from each mix, for both tests. The results were taken to be the arithmetic mean of the 8 values obtained.

At the same time, the pore size distribution of the concrete was determined with a Micromeritics AutoPore III mercury porosimeter to analyze the pore structure. Samples weighing approximately $2 \mathrm{~g}$ were taken from the upper and lower zones of the prismatic specimens used in the absorption tests, and dried in an oven at $110^{\circ} \mathrm{C}$.

\section{RESULTS AND DISCUSSION}

\subsection{Segregation}

According to a study by Bui et al. (12), an SCC may be regarded to satisfactorily resist segregation if the variation in coarse aggregate content with height, $R_{v}$ calculated by the following expression [1], is less than $10 \%$.

$$
R_{v}(\%)=100 \sqrt{\frac{\sum_{i=1}^{n}\left(\frac{x_{i}-\bar{x}}{\bar{x}}\right)^{2}}{n}}
$$

Tabla 2 / Table 2

Resultado de los ensayos de slump flow y $V$-funnel Slump and $V$-funnel test results

\begin{tabular}{|c|c|c|c|c|}
\hline \multirow[b]{2}{*}{ Hormigón / Concrete } & \multicolumn{3}{|c|}{ Slump flow } & \multirow[b]{2}{*}{$\begin{array}{c}\text { V-funnel } \\
T(s)\end{array}$} \\
\hline & $T_{50}(s)$ & $\varnothing_{\mathrm{f}}(\mathrm{cm})$ & $\begin{array}{c}\text { Segregación visible } \\
\text { Perceptible segregation }\end{array}$ & \\
\hline A-65-32 & 3.2 & 69 & No & 9.9 \\
\hline$A-55-32$ & 3.8 & 70 & No & 12.1 \\
\hline A-55-42 & 3.7 & 64 & No & 12.0 \\
\hline A-45-42 & 5.1 & 65 & No & 14.6 \\
\hline
\end{tabular}


siendo:

n número de partes en que se subdivide la probeta de hormigón.

$\mathrm{x}_{\mathrm{i}}$ relación entre el peso de árido grueso de más de 8 $\mathrm{mm}$ y el peso de hormigón de cada parte.

$\bar{x}$ relación entre el peso total de árido grueso de más de $8 \mathrm{~mm}$ y el peso total de hormigón.

Por otra parte, según el Institute of Building Materials Science and Testing de Munich, se puede considerar que una mezcla es estable si la variación del contenido de árido grueso (de más de $8 \mathrm{~mm}$ ) en la parte superior de la pieza respecto del contenido medio de árido en toda la pieza, $\Delta_{1}$, es inferior al $20 \%$ (7). Dicha variación se obtiene mediante la siguiente expresión [2]: where:

$n$ number of units into which the concrete specimen is divided.

$x_{i}$ ratio between weight of coarse aggregate over $8 \mathrm{~mm}$ and weight of concrete in each portion of specimen.

$\bar{x}$ ratio between total weight of coarse aggregate measuring more than $8 \mathrm{~mm}$ and total weight of concrete.

Moreover, according to the Institute of Building Materials Science and Testing at Munich, a mixture can be regarded to be stable if the variation in coarse aggregate content (over $8 \mathrm{~mm}$ ) in the upper part of the specimen, compared to the average aggregate content in the specimen as a whole, $\Delta_{1}$, is less than $20 \%$ (7). The variation may be computed from the expression [2]:

$$
\Delta_{i}(\%)=\left(\frac{x_{i}}{\bar{x}}-1\right) \cdot 100
$$

Tomando como referencia ambos criterios, en la Tabla 3 y en la Figura 2 se han recogido los distintos resultados obtenidos, pudiendo observarse que todos los HAC presentan un buen comportamiento frente a la segregación, puesto que en los cuatro casos analizados tanto el valor de $\mathrm{R}_{\mathrm{v}}$ como el de $\Delta_{1}$ están claramente dentro de los límites de aceptación. Las mayores variaciones se han registrado en la amasada A-45-42, donde estos dos parámetros son iguales al 5,53\% y al 9,81\%, respectivamente. Estos resultados confirman además las impresiones obtenidas a partir de la simple inspección visual de las mezclas tras el ensayo de slump flow, donde ninguna de ellas presentaba signos externos de segregación (acumulación de árido grueso en el centro de la torta o formación de un halo de agua en el extremo de la misma).

Aunque es sabido que a medida que aumenta la fluidez del hormigón, su estabilidad disminuye, si se intentan relacionar los datos de segregación con los que se obtienen en los ensayos de slump flow o $V$-funnel, los coeficientes de correlación $\mathrm{R}^{2}$ que se alcanzan son muy bajos, inferiores a 0,6. De hecho, hay amasadas en las que el diámetro final $\emptyset_{f} \circ$ el tiempo de vaciado del embudo son muy parecidos (Tabla 2) y, sin embargo, la resistencia a la segregación es distinta (Tabla 3 ). Estos resultados vienen a reforzar la idea de algunos investigadores, como Lowke et al. (7), que señalan que los ensayos de slump flow y $V$-funnel no son suficientemente sensibles para cuantificar la estabilidad de una mezcla, dado que el fenómeno de la segregación no depende sólo de la fluidez del material, sino que intervienen otros factores, tales como la viscosidad plástica, la tixotropia o la granulometría, que interfieren unos sobre otros (5).
The results for the above two criteria given in Table 3 and Figure 2 show that all the SCCs performed well in terms of resistance to segregation, since in the four cases analyzed the values of both $R_{v}$ and $\Delta_{1}$ were clearly within the acceptable limits. The greatest variation was found for mix A-45-42, where the two parameters were $5.53 \%$ and $9.81 \%$, respectively. These results also confirmed the impression obtained from the visual inspection of the mixtures after the slump test, when none showed signs of segregation (concentration of coarse aggregate in the centre of the patty or formation of a ring of water around its edge).

While concrete stability is known to decrease as fluidity increases, attempts to obtain a relationship between segregation and slump or $V$-funnel test results generally yield very low $R^{2}$ correlation coefficients, with values of under 0.6. Indeed, in some batches with similar final patty diameters, $\varnothing_{f}$, or funnel emptying times (Table 2), the segregation resistance differed (Table 3). These results support the theories sustained by researchers such as Lowke et al. (7) to the effect that the slump and $V$-funnel tests are not sensitive enough to quantify mixture stability, since segregation depends not only on fluidity but also involves other factors, such as plastic viscosity, thixotropy and particle size distribution, all of which interact (5). 
Tabla 3 / Table 3

Resultados del ensayo de segregación

Segregation test results

\begin{tabular}{|c|c|c|}
\hline Hormigón / Concrete & Rv (\%) & $\mathbf{\Delta}_{\mathbf{1}} \mathbf{( \% )}$ \\
\hline A-65-32 & 4.95 & -8.20 \\
\hline A-55-32 & 4.52 & -7.10 \\
\hline A-55-42 & 2.75 & -4.01 \\
\hline A-45-42 & 5.53 & -9.81 \\
\hline T-65-32 & 3.81 & -6.79 \\
\hline T-55-32 & 2.19 & -2.12 \\
\hline T-55-42 & 2.51 & -1.79 \\
\hline T-45-42 & 2.00 & -1.31 \\
\hline
\end{tabular}

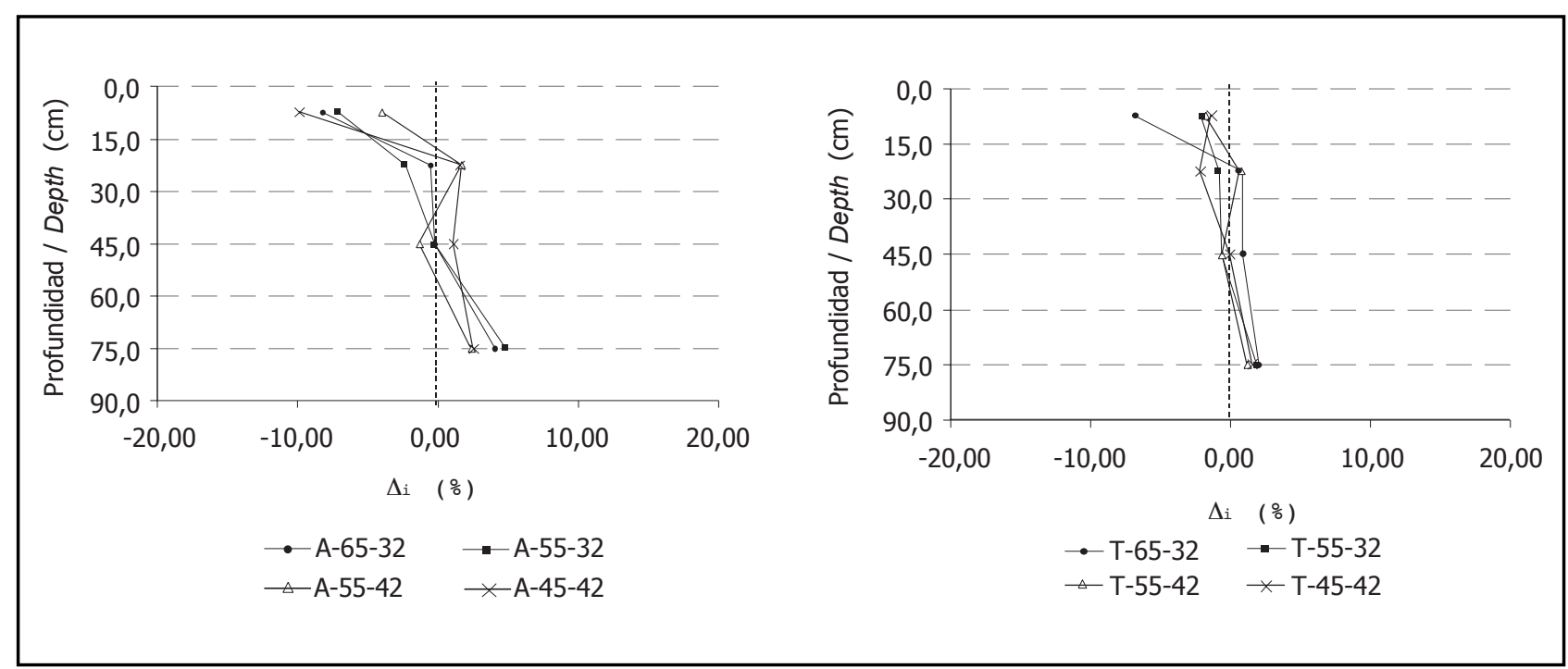

Figura 2. Variación del contenido de árido grueso con la profundidad.

Figure 2. Variation of coarse aggregate content with depth.

Por lo que respecta al comportamiento de los HAC en relación con los $\mathrm{HT}$, estos últimos presentan una mayor homogeneidad (Figura 2). De hecho, el índice de segregación $\Delta_{1}$ en los cuatro HAC estudiados es por término medio igual al 7,3\% frente al 3,0\% obtenido en los HT. El análisis estadístico de los resultados mediante un ANOVA y mediante modelos de regresión lineal múltiple revela además que las diferencias que se registran entre ambos tipos de hormigones son estadísticamente significativas ( $p$-value $=0,008$ ). En cualquier caso, a pesar de la mayor segregación registrada en los $\mathrm{HAC}$, no hay que olvidar que en las cuatro dosificaciones los índices de segregación están claramente dentro de los límites de aceptación. En consecuencia, se puede señalar que mediante una cuidada dosificación se puede fabricar hormigones que sin necesidad de ser vibrados presentan una buena resistencia a la segregación, lo que les confiere grandes ventajas durante los procesos de ejecución de una obra.
Although SCC homogeneity was found to be acceptable, this material was less uniform than TC (Figure 2), with a mean segregation index, $\Delta_{1}$, for the four types of SCC of 7.3\% compared to $3.0 \%$ for TC. ANOVA and multiple linear regression model statistical analysis revealed that the differences between the two types of concrete were statistically significant ( $p$-value $=0.008$ ). Despite these differences, however, it should be stressed that the segregation indices for the four mixes were clearly within acceptable limits. With a carefully designed mix, therefore, self-consolidating concretes can be made to be highly segregation-resistant, which is enormously beneficial in construction work. 


\subsection{Porosidad}

Los resultados de los distintos tipos de ensayos realizados para determinar la porosidad del hormigón están recogidos en la Tabla 4. Como era de esperar, tanto en el caso de los HAC como en el de los HT, a medida que disminuye la relación $\mathrm{a} / \mathrm{c}$ o se emplean cementos de mayor clase resistente, la porosidad disminuye, dando lugar a una menor absorción y a una menor permeabilidad al agua bajo presión. Además, se verifica que existe una variación de la porosidad con la altura (Figura 3).

\section{a) Microestructura del hormigón}

Si se comparan las amasadas A-65-32 y A-45-42 con sus respectivas amasadas de referencia T-65-32 y T-45-42, todos los parámetros medidos en los ensayos de porosimetría (densidad aparente, $\mathrm{d}_{16}$, porosidad abierta y volumen total de poros) tienden a ser ligeramente más uniformes con la altura en los HAC (Tabla 4). Por otro lado, tomando como referencia estas mismas amasadas, en la Figura 4 se observa que la distribución de tamaños de poro normalizada también se mantiene más uniforme en los HAC. Las diferencias entre las distintas zonas de una misma probeta afectan principalmente al porcentaje de poros capilares (tamaño entre $0,01 \mu \mathrm{m}$ y $1 \mu \mathrm{m})$, siendo éstos, junto con los macroporos, los que verdaderamente van a incidir sobre la permeabilidad del material, ya que en los poros de gel (tamaño inferior a $0,01 \mu \mathrm{m}$ ) difícilmente va a poder penetrar el agua.

Curiosamente, esta mayor homogeneidad que tienden a presentar los HAC en su microestructura se contrapone,

\subsection{Porosity}

The results of the various tests conducted to determine concrete porosity are given in Table 4. Due to the smaller $w / c$ ratio in higher strength cements, porosity was unsurprisingly found to be lower in both the SCCs and TCS made with $42.5 R$ cement, all of which exhibited lower absorption and permeability to pressurized water. Moreover, porosity was observed to vary with column height (Figure 3).

\section{a) Concrete microstructure}

A comparison of the results for mixes A-65-32 and A-4542 and the respective controls T-65-32 and T-45-42 showed that the porosimetry test parameters (bulk density, $d_{16}$ open porosity and total pore volume) tended to be slightly more uniform with height in the SCCS (Table 4). Standardized pore size distribution also proved to be more uniform in the SCCS (see Figure 4). The parameter showing variations in the different zones of a given specimen was the percentage of capillary pores (sizes between $0.01 \mu \mathrm{m}$ and $1 \mu \mathrm{m}$ ). Together with the macropores, this is the fraction that has a material effect on permeability, since it is difficult for water to penetrate the gel pores (under $0.01 \mu \mathrm{m}$ ).

Such greater homogeneity in SCC microstructure would appear to contradict the lower resistance to segregation

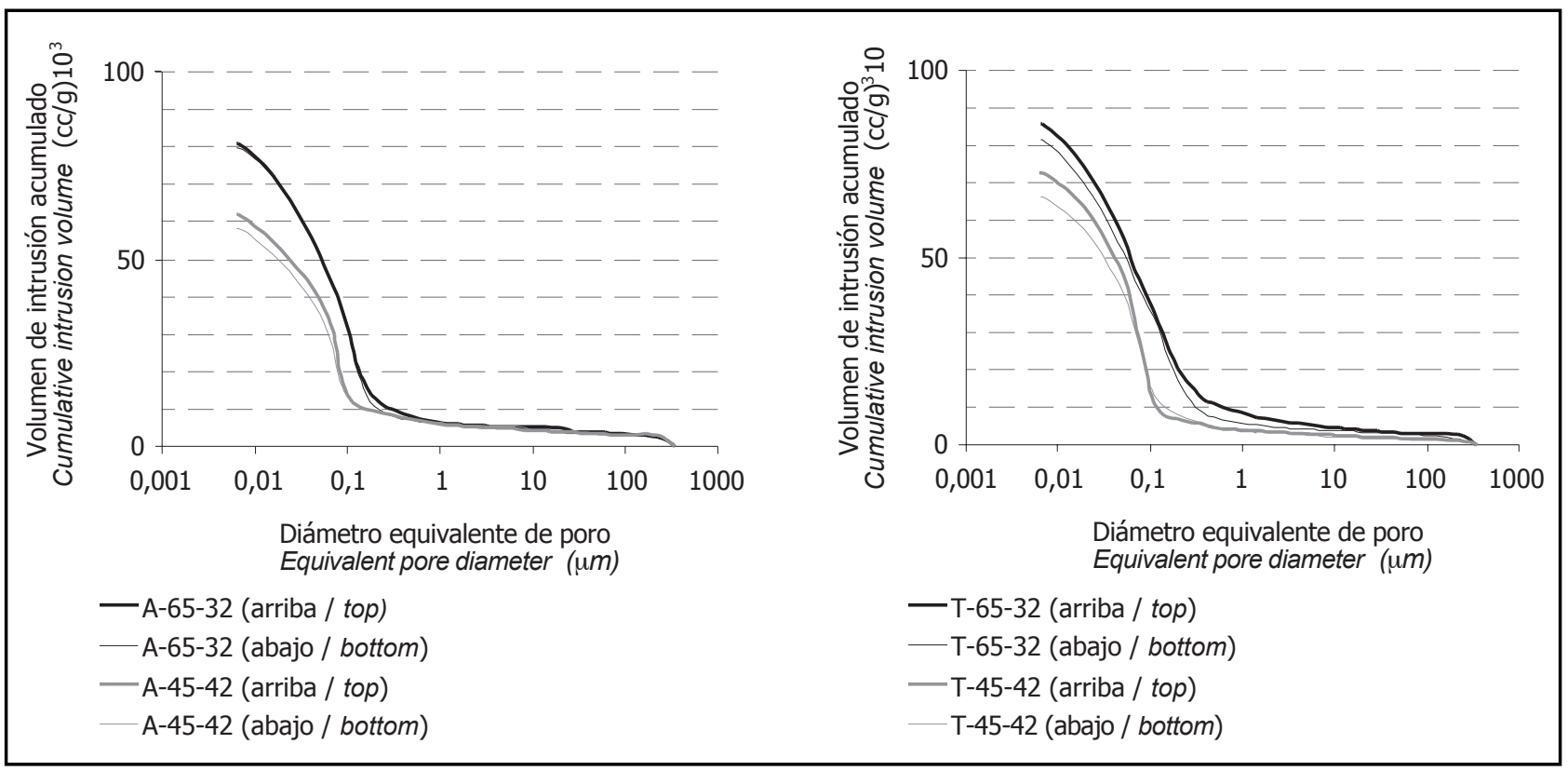

Figura 3. Variación del contenido de árido grueso con la profundidad.

Figure 3. Variation of coarse aggregate content with depth. 
Tabla 4 / Table 4

Resultados de los ensayos de absorción, permeabilidad y porosimetría Absorption, permeability and porosimetry test results

\begin{tabular}{|c|c|c|c|c|c|c|c|}
\hline \multirow{2}{*}{$\begin{array}{l}\text { Hormigón } \\
\text { Concrete }\end{array}$} & \multirow{2}{*}{$\begin{array}{l}\text { Zona } \\
\text { Zone }\end{array}$} & \multirow{2}{*}{$\begin{array}{c}\text { Absorción } \\
\text { Absorption } \\
\text { (\%) }\end{array}$} & \multirow{2}{*}{\begin{tabular}{|c|} 
Prof. penetración \\
Penetration \\
depth \\
$(\mathbf{m m})$ \\
\end{tabular}} & \multicolumn{4}{|c|}{ Porosimetría / Porosimetry } \\
\hline & & & & $\begin{array}{c}\text { Densidad aparente } \\
\text { Bulk density } \\
\left(\mathrm{g} / \mathrm{cm}^{3}\right)\end{array}$ & $\begin{array}{c}d_{16}(*) \\
(\mu \mathrm{m})\end{array}$ & $\begin{array}{c}\text { Porosid. abierta } \\
\text { Open porosity } \\
\text { (\%) }\end{array}$ & $\begin{array}{c}\text { Vol. total poros } \\
\text { Total pore vol. } \\
\left(\mathbf{g} / \mathrm{cm}^{3}\right)\end{array}$ \\
\hline A-65-32 & $\begin{array}{l}\text { Arriba / Top } \\
\text { Medio / Middle } \\
\text { Abajo / Bottom }\end{array}$ & $\begin{array}{l}6.13 \\
6.06 \\
5.93\end{array}$ & $\begin{array}{l}26 \\
22 \\
20\end{array}$ & $\begin{array}{c}2.154 \\
--- \\
2.151\end{array}$ & $\begin{array}{c}0.17 \\
--- \\
0.15\end{array}$ & $\begin{array}{c}16.8 \\
--- \\
16.6\end{array}$ & $\begin{array}{c}0.0782 \\
--- \\
0.0774\end{array}$ \\
\hline A-55-32 & $\begin{array}{l}\text { Arriba / Top } \\
\text { Medio / Middle } \\
\text { Abajo / Bottom }\end{array}$ & $\begin{array}{l}5.64 \\
5.58 \\
5.44 \\
\end{array}$ & $\begin{array}{l}22 \\
17 \\
14 \\
\end{array}$ & $\begin{array}{c}2.208 \\
--- \\
2.181 \\
\end{array}$ & $\begin{array}{c}0.16 \\
--- \\
0.13\end{array}$ & $\begin{array}{c}14.7 \\
--- \\
15.0\end{array}$ & $\begin{array}{c}0.0664 \\
--- \\
0.0689\end{array}$ \\
\hline A-55-42 & $\begin{array}{l}\text { Arriba / Top } \\
\text { Medio / Middle } \\
\text { Abajo / Bottom }\end{array}$ & $\begin{array}{l}5.28 \\
5.24 \\
5.16\end{array}$ & $\begin{array}{l}16 \\
12 \\
10\end{array}$ & $\begin{array}{c}2.206 \\
--- \\
2.227\end{array}$ & $\begin{array}{c}0.11 \\
--- \\
0.12\end{array}$ & $\begin{array}{c}14.4 \\
--- \\
13.5\end{array}$ & $\begin{array}{c}0.0651 \\
--- \\
0.0608\end{array}$ \\
\hline A-45-42 & $\begin{array}{l}\text { Arriba / Top } \\
\text { Medio / Middle } \\
\text { Abajo / Bottom }\end{array}$ & $\begin{array}{l}4.43 \\
4.36 \\
4.34 \\
\end{array}$ & $\begin{array}{c}10 \\
8 \\
7 \\
\end{array}$ & $\begin{array}{c}2.199 \\
--- \\
2.232 \\
\end{array}$ & $\begin{array}{c}0.11 \\
--- \\
0.11 \\
\end{array}$ & $\begin{array}{c}13.0 \\
--- \\
12.3 \\
\end{array}$ & $\begin{array}{c}0.0590 \\
--- \\
0.0553 \\
\end{array}$ \\
\hline$T-65-32$ & $\begin{array}{l}\text { Arriba / Top } \\
\text { Medio / Middle } \\
\text { Abajo / Bottom }\end{array}$ & $\begin{array}{l}6.25 \\
6.01 \\
5.60 \\
\end{array}$ & $\begin{array}{l}59 \\
49 \\
42 \\
\end{array}$ & $\begin{array}{c}2.118 \\
--- \\
2.134 \\
\end{array}$ & $\begin{array}{c}0.27 \\
--- \\
0.23 \\
\end{array}$ & $\begin{array}{c}17.6 \\
--- \\
17.0 \\
\end{array}$ & $\begin{array}{c}0.0832 \\
--- \\
0.0797 \\
\end{array}$ \\
\hline$T-55-32$ & $\begin{array}{l}\text { Arriba / Top } \\
\text { Medio / Middle } \\
\text { Abajo / Bottom }\end{array}$ & $\begin{array}{l}5.74 \\
5.62 \\
5.25 \\
\end{array}$ & $\begin{array}{l}45 \\
33 \\
36 \\
\end{array}$ & $\begin{array}{l}--- \\
--- \\
--- \\
\end{array}$ & $\begin{array}{l}--- \\
--- \\
--- \\
\end{array}$ & $\begin{array}{l}--- \\
--- \\
--- \\
\end{array}$ & $\begin{array}{l}--- \\
--- \\
--- \\
\end{array}$ \\
\hline$T-55-42$ & $\begin{array}{l}\text { Arriba / Top } \\
\text { Medio / Middle } \\
\text { Abajo / Bottom }\end{array}$ & $\begin{array}{l}5.17 \\
5.05 \\
4.83 \\
\end{array}$ & $\begin{array}{l}24 \\
22 \\
20 \\
\end{array}$ & $\begin{array}{l}--- \\
--- \\
--- \\
\end{array}$ & $\begin{array}{l}--- \\
--- \\
--- \\
\end{array}$ & $\begin{array}{l}--- \\
--- \\
--- \\
\end{array}$ & $\begin{array}{l}--- \\
--- \\
--- \\
\end{array}$ \\
\hline$T-45-42$ & $\begin{array}{l}\text { Arriba / Top } \\
\text { Medio / Middle } \\
\text { Abajo / Bottom }\end{array}$ & $\begin{array}{l}4.79 \\
4.70 \\
4.57\end{array}$ & $\begin{array}{l}19 \\
15 \\
16\end{array}$ & $\begin{array}{c}2.126 \\
--- \\
2.164\end{array}$ & $\begin{array}{c}0.13 \\
--- \\
0.11\end{array}$ & $\begin{array}{c}15.2 \\
--- \\
14.1\end{array}$ & $\begin{array}{c}0.0782 \\
--- \\
0.0715\end{array}$ \\
\hline
\end{tabular}

(*) Diámetro de poro correspondiente a un volumen de intrusión de mercurio del $16 \%$ / Pore diameter for a mercury intrusion volume of $16 \%$.

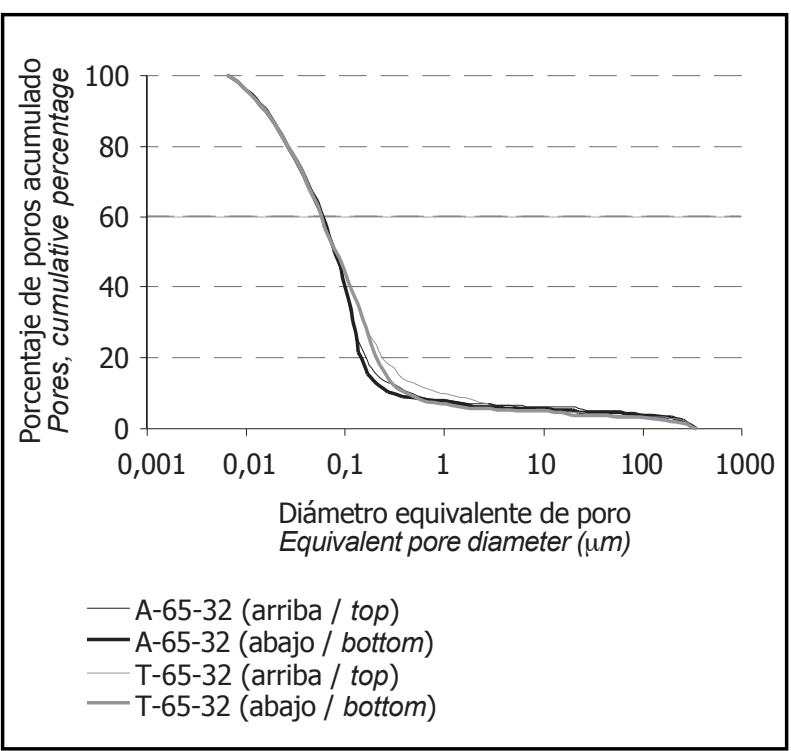

Figura 4. Distribución de tamaños de poro normalizada. Figure 4. Standardized pore size distribution.

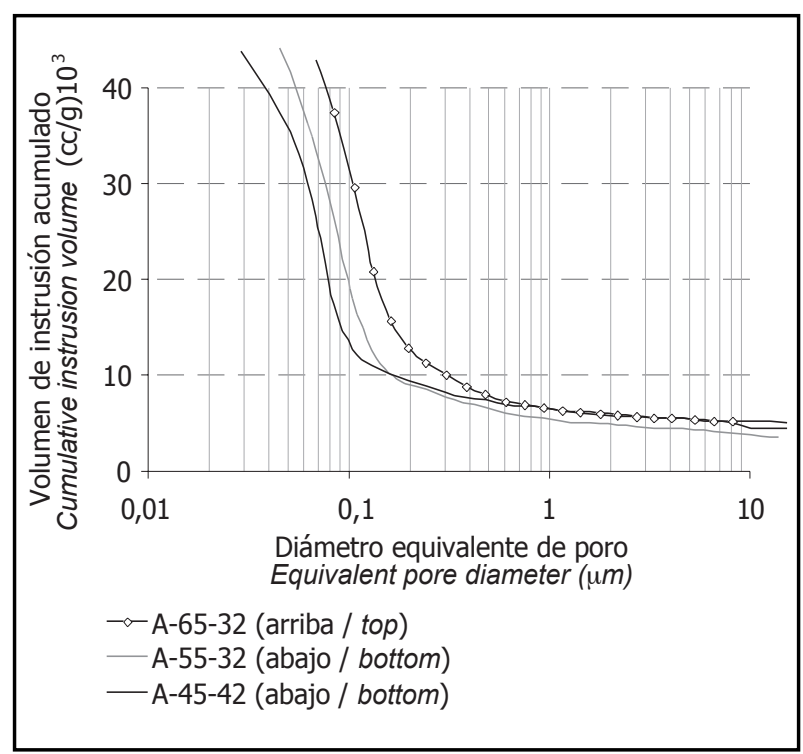

Figura 5. Distribución de tamaños de poro. Figure 5. Pore size distribution. 
en principio, con su menor resistencia a la segregación, ya que, según lo visto en el apartado anterior, al haberse registrado un mayor asiento de las partículas más grandes en los HAC, la migración de agua hacia la superficie debería haber sido mayor $y$, por tanto, las diferencias de porosidad entre las zonas inferior y superior de las piezas también deberían haber sido mayores. Esta aparente discrepancia puede justificarse por el menor sangrado que experimentan los HAC debido a la acción de los finos calizos que, presentes en más cantidad que en los HT, son capaces de retener gran parte del agua libre (23). Además, no hay que olvidar que la vibración que se realiza en los HT facilita el sangrado, creándose canales de sangrado y, por tanto, una red de poros capilares interconectados (27). Por otra parte, los finos actúan como cohesionantes, propiciando un descenso más lento de los áridos durante el cual la elevada fluidez del HAC permite que se rellenen los huecos, obstaculizando los caminos que el agua genera al ascender y dando lugar así a una red capilar más tortuosa.

\section{b) Penetración de agua bajo presión}

De acuerdo con los datos recogidos en la Tabla 4, en todos los casos analizados el HAC presenta un mejor comportamiento frente a la permeabilidad que el HT (28). Ahora bien, tal y como se deduce del ANOVA de los resultados, las diferencias de permeabilidad entre ambos tipos de hormigón dependen de la dosificación ( $p$-value $=0,01$ ), tendiendo a disminuir dichas diferencias a medida que mejora la calidad del hormigón. De hecho, por término medio, el agua penetra en los HAC $27 \mathrm{~mm}$ menos que en los HT para la dosificación 1, $20 \mathrm{~mm}$ menos para la dosificación 2, $10 \mathrm{~mm}$ menos para la dosificación 3 y $9 \mathrm{~mm}$ menos para la dosificación 4 . Este mejor comportamiento por parte de los HAC los hace especialmente interesantes frente a criterios de durabilidad. La menor permeabilidad es debida a un mejor empaquetamiento de las partículas en los HAC como consecuencia de la adición de los finos calizos (23), los cuales hacen la distribución de partículas más ancha, proporcionando una matriz cementante más densa al ocupar los espacios entre las partículas de cemento que, de otro modo, estarían ocupados por agua, lo que se traduce, tal y como se observa en los ensayos de porosimetría, en una mayor densidad aparente, una menor porosidad y un menor tamaño medio de poro que en los $\mathrm{HT}$. Este mejor empaquetamiento de las partículas, además de originar una menor porosidad total en el hormigón, hace que la red de poros sea más tortuosa, por lo que, según la ley de Darcy de circulación de fluidos por un lecho poroso, el coeficiente de permeabilidad del material es más bajo, dado que éste es directamente proporcional a la porosidad del sólido y al cuadrado del radio medio del poro, e inversamente proporcional al cuadrado de la tortuosidad de la estructura porosa. in this material, for the settling of a higher proportion of the larger particles in the SCCS noted above should have translated into a greater transfer of water towards the surface, with concomitantly larger differences in porosity between the upper and lower zones of the specimens. This apparent discrepancy may be explained by the lesser amount of bleeding in SCCS as a result of the limestone fines, which, present in higher quantities than in the TCS, are able to retain much of the free water (23). TC vibration, moreover, facilitates bleeding and creates bleeding channels as well as a network of interconnected capillary pores (27). Finally, the fines act as viscosityenhancing agents, causing the aggregates to descend more slowly, during which process the high fluidity of the SCC contributes to filling in the gaps and blocking the channels made by the rising water, thereby generating a more intricate capillary network.

\section{b) Pressurized water penetration}

The data in Table 4 show that in all the cases analyzed SCC resisted water absorption better than TC (28). It may be deduced from the ANOVA results, however, that the differences in water absorption between the two types of concrete depended on the mix ( $p$-value $=0.01$ ), for they tended to decline with improving concrete quality. Water penetration in the SCCS was lower than in the TCs by an average $27 \mathrm{~mm}$ for mix 1, $20 \mathrm{~mm}$ for mix 2, $10 \mathrm{~mm}$ for mix 3 and $9 \mathrm{~mm}$ for mix 4 . Such lower permeability, which renders the SCCs more durable than the respective TCS, is due to the better particle packing afforded by the limestone fines (23), which broaden particle size distribution and provide a denser matrix by occupying the spaces between the cement particles that would otherwise be occupied by water. The outcome is greater bulk density, lower porosity and smaller mean pore size than in the TCs, as the results of the porosimetry tests show. Improved particle packing, in addition to generating lower total porosity in the concrete, makes the pore network more intricate. According to Darcy's Law on the circulation of fluids through a permeable substance, this reduces the permeability coefficient of the material, which is directly proportional to the porosity of the solid and to the square of the mean pore radius, and inversely proportional to the square of pore structure intricacy. 
Por lo que respecta a la uniformidad de la mezcla con la altura, todos los hormigones analizados presentan un comportamiento muy similar, excepción hecha del HT fabricado con una relación a/c igual a 0,65 (T-65-32) donde, debido probablemente a un mayor sangrado, las variaciones de permeabilidad con la altura tienden a ser algo mayores. Así, por ejemplo, mientras que las diferencias de penetración de agua entre las zonas superior e inferior de las piezas son, por término medio, de 17 $\mathrm{mm}$ para la dosificación T-65-32, en el resto de hormigones estas diferencias no superan los $9 \mathrm{~mm}$.

\section{c) Absorción de agua}

La absorción de agua en ambos tipos de hormigón es muy similar para cada una de las dosificaciones estudiadas. De hecho, por término medio, las diferencias relativas entre HAC y HT son del 1,7 , del 0,9 , del 4,2 y del $6,8 \%$ para las dosificaciones 1, 2, 3 y 4, respectivamente (Tabla 4). Ahora bien, por lo que respecta a la homogeneidad del material, el análisis estadístico de los resultados revela una variación de la absorción con la altura más importante en los HT que en los HAC ( $p$-value $=0,004$ ), variación que sólo en el caso de los HT depende también de la dosificación ( $p$-value $=0,02$ ). Así, por ejemplo, mientras que en los HAC las diferencias relativas de absorción entre las partes superior e inferior de las columnas son sensiblemente las mismas y aproximadamente iguales al 3\% para las 4 dosificaciones, en el caso de los HT las diferencias son del 12, 9, 7 y $5 \%$ para las dosificaciones $1,2,3$ y 4 , respectivamente. Es decir, los HAC presentan una mayor homogeneidad con la altura, si bien las diferencias con los HT tienden a desaparecer a medida que aumenta la calidad del hormigón.

Si se comparan entre sí los datos de absorción y de permeabilidad, se observa que las variaciones entre distintas zonas de una misma probeta o entre distintos hormigones son mucho mayores en los ensayos de permeabilidad. Para entender esta cuestión hay que recurrir a los ensayos de porosimetría, pudiendo observarse en la Figura 5, donde se han representado sólo algunas amasadas, que para tamaños de poro superiores aproximadamente a $0,5 \mu \mathrm{m}$ el volumen de intrusión de mercurio tiende a ser similar en todas las muestras tomadas, situación que coincide con la registrada en los ensayos de absorción, donde la penetración de agua es simplemente por capilaridad. No obstante, para tamaños de poro inferiores $y$, por lo tanto, sólo accesibles por el agua cuando se aplica una cierta presión, las diferencias entre las distintas muestras se acentúan notablemente. Es decir, el análisis microestructural realizado parece indicar que cuando la penetración de agua es por succión capilar, ambos tipos de hormigones presentan comportamientos similares, si bien cuando la penetración de agua es por presión hidráulica los HAC son mucho más impermeables, lo que les confiere, desde ese punto de vista, mayor durabilidad.
All the concretes analyzed exhibited similar behaviour in terms of mixture uniformity with height, with the exception of the TC made with a w/c ratio of 0.65 (T-65-32), in which, probably due to greater bleeding, the variation of permeability with height was observed to be somewhat greater. Indeed, while the difference in water penetration between the upper and lower zones of the T-65$32 \mathrm{mix}$ specimens was $17 \mathrm{~mm}$ on average, in all the other mixes this differences was no greater than $9 \mathrm{~mm}$.

\section{c) Water absorption}

Water absorption was very similar for all the mixes studied in both types of concrete. On average, the relative differences between SCC and TC were 1.7, 0.9, 4.2 and $6.8 \%$ for mixes 1, 2, 3 and 4, respectively (Table 4). A statistical analysis of the results of material homogeneity, however, revealed a greater variation in absorption with height in the TCs than in the SCCS ( $p$-value = 0.004). Moreover, variation was found to also depend on the mix in the TCs only ( $p$-value $=0.02$ ). Thus, for example, while in the SCCs the relative differences in absorption between the upper and lower zones of the columns were very similar and approximately $3 \%$ for the four mixes, in the TCs the differences were 12, 9, 7 and 5\% for mixes 1, 2, 3 and 4, respectively. The SCCS, in other words, exhibited greater homogeneity with height, although the differences between the two types of material tapered with increasing concrete quality.

The variations between zones on the same specimen or between different types of concrete were found to be much greater for permeability than for absorption data. An explanation for this finding should be sought in the porosimetry test results. As Figure 5 (which plots only some of the mixes) shows, for pore sizes greater than approximately $0.5 \mu \mathrm{m}$ the mercury intrusion volume was essentially similar in all the samples. This observation concurs with the results of the absorption tests, which showed that water was absorbed simply by capillarity. For smaller pore sizes that are accessible to pressurized water, however, substantially larger differences were found between the various samples. In other words, the microstructural analysis conducted seems to indicate that when water penetrates by capillary action the two types of concrete exhibit similar behaviour, but when hydraulic pressure is involved, the SCCs are much more water resistant and hence more durable. 


\section{CONCLUSIONES}

De acuerdo con el trabajo experimental realizado, se pueden establecer las siguientes conclusiones:

- Los HAC presentan una buena resistencia a la segregación, pues, aunque su índice de segregación $\Delta_{1}$ es, por término medio, un $4 \%$ superior al de los HT de consistencia fluida, dicho índice está claramente dentro de los límites de aceptación.

- Los ensayos de slump flow y $V$-funnel no son suficientemente sensibles para cuantificar la estabilidad de una mezcla, debiendo recurrir a ensayos específicos tales como el realizado en este trabajo.

- Los HAC presentan una estructura porosa más homogénea que los HT. Las diferencias entre las zonas superior e inferior de una misma probeta afectan principalmente al volumen de poros capilares, siendo estas diferencias mayores en los HT.

- Debido a un mejor empaquetamiento de las partículas en los HAC, además de generarse una red de poros más tortuosa, dichos hormigones presentan una mayor densidad aparente, una menor porosidad y un menor tamaño medio de poro que los $\mathrm{HT}$, lo que les confiere mejores prestaciones frente a la penetración de agua bajo presión $y$, por tanto, desde ese punto de vista, mayor durabilidad. No obstante, para diámetros de poro superiores aproximadamente a 0,5 $\mu \mathrm{m}$ la distribución de tamaños de poro es similar en ambos tipos de hormigón, dando lugar a una absorción también similar, con diferencias entre ellos inferiores al $6,8 \%$ en las cuatro dosificaciones analizadas.

- El incremento de permeabilidad con la altura es parecido en ambos tipos de hormigón (diferencias de penetración de agua inferiores en general a $9 \mathrm{~mm}$ ), excepción hecha del HT fabricado con una relación a/c igual a 0,65 donde, debido probablemente a un mayor sangrado, dicho incremento tiende a ser del orden del doble.

- Desde el punto de vista de la absorción, los HAC presentan una mayor homogeneidad a lo largo de la altu$\mathrm{ra}$, si bien las diferencias con los HT tienden a desaparecer a medida que aumenta la calidad del hormigón.

\section{AGRADECIMIENTOS}

Los autores de este trabajo manifiestan su agradecimiento a los técnicos de laboratorio R. Calabuig y J. Martínez y al Instituto de Tecnología Cerámica de Castellón por su desinteresada colaboración en la realización de los ensayos. Asimismo, se agradece al Área de Apoyo Lingüístico a la I+D+i de la Universidad Politécnica de Valencia su ayuda en la traducción de este artículo. Finalmente, reseñar que los materiales utilizados en este estudio han sido gentilmente suministrados por CEMEX, DEGUSSA y HORLESA.

\section{CONCLUSIONS}

The following conclusions can be drawn from the foregoing empirical results:

- SCCS resist segregation well, for although the segregation index, $\Delta_{1}$, recorded for these concretes is on average $4 \%$ greater than found for TCs, it is clearly within acceptable limits.

- Slump and V-funnel test sensitivity is insufficient to quantify mixture stability. Other specific tests, such as undertaken in this study, are required.

- SCCS have a more uniform pore structure than TCS. The main difference between the upper and lower zones of specimens is found in the volume of capillary pores, with larger differences observed in TCS.

- Due to better particle packing and the generation of more intricate pore networks, SCCs exhibit greater bulk density, lower porosity and smaller mean pore size than TCs. Consequently, they perform better when exposed to pressurized water and are more durable. For pore diameters greater than approximately $0.5 \mu \mathrm{m}$, however, the pore size distribution and therefore absorption are similar in the two types of concrete, with differences of only $6.8 \%$ or less in the four mixes analyzed.

- Permeability increased with height by around two-fold in the two types of concrete (as a rule, water penetration differed by less than $9 \mathrm{~mm}$ ), with the sole exception of the TC made with a w/c ratio of 0.65 , where the increase was higher, probably due to greater bleeding.

- The SCCs exhibited greater homogeneity with height in terms of absorption, although the differences between the two types of material tapered with increasing concrete quality.

\section{ACKNOWLEDGEMENTS}

The authors with to thank laboratory technicians $R$. Calabuig and J. Martínez as well as the Instituto de Tecnología Cerámica de Castellón for their support in conducting the tests. Acknowledgements are likewise due to the Polytechnic University of Valencia's R\&D Language Support Department for their assistance in the translation of this article. CEMEX, DEGUSSA and HORLESA generously supplied the materials used for testing. 


\section{BIBLIOGRAFÍA / BIBLIOGRAPHY}

(1) Saak, A.W., Jenning, H. y Shah, S.: "New methodology for designing self-compacting concrete", ACI Materials Journal, vol. 98 , n 6 (2001), pp. 429-439.

(2) Jossic, L. y Magnin, A.: "Trainée et satbilité d'objet en fluide á seuil", Les Cahiers de Rhéologie, vol. 18, no 1 (2001), pp. 55-64.

(3) Beris, A. N., Tsamopoulos, J. A., Armstrong, R. C. y Brown, R. A.: "Creeping motion of a sphere through a Bingham plastic", Journal of Fluid Mechanics, no 158 (1985), pp. 219-244.

(4) Bethmont, S., Aloia, L. D', Stefani, C. y Leroy, R.: "Defining the satbility criterion of a sphere suspended in a cement paste: a way to study the segregation risk in self-compacting concrete (SCC)", Proceedings of 3 rd international RILEM symposium on self-compacting concrete, Reykjavik, 2003, pp. 94-105.

(5) Wallevik, O. H.: "Rheology, a scientific approach to develop self-compacting concrete", Proceedings of $3^{\text {rd }}$ international RILEM symposium on self-compacting concrete, Reykjavik, 2003, pp. 23-31.

(6) Jolicoeur, C., Khayat, K. H., Pavate, T. V. y Pagé, M.: "Evaluation of effect of chemical admixture and supplementary cementitious materials on stability of concrete-based materials using in-situ conductivity method. Superplasticizers and other chemical admixtures in concrete", Proceedings of the sixth CANMET/ACI international conference, pp. 461-483, SP-195, en Malhotra, V. M. (ed.), American Concrete Institute, Farmington Hills, Michigan, 2000.

(7) Lowke, D., Wiegrink, K. y Schiessl, P.: "A simple and significant segregation test for SCC", Proceedings of 3rd international RILEM symposium on self-compacting concrete, Reykjavik, 2003, pp. 358-366.

(8) Petrov, N., Khayat, K. H. y Tagnit-Hamou, A.: "Effect of stability of self-consolidating concrete on the distribution of steel corrosion characteristics along experimental wall elements", Proceedings of $2^{\text {nd }}$ international RILEM symposium on self-compacting concrete, Tokyo, 2001, pp. 441-450.

(9) Bartos, P.: "Towards new European Standards for Fresh SCC", Design, Performance and Use of Self-Consolidating Concrete (SCC'2005-China), pp. 25-44.

(10) Daczko, J. y Kurtz, M.: "Development of high volume coarse aggregate self-compacting concrete", Proceedings of 2nd international RILEM symposium on self-compacting concrete, Tokyo, 2001, pp. 403-412.

(11) Omoto, T. y Ozawa, K. (eds.), Recommendation for self-compacting concrete, JSCE Concrete Engineering Series 31, Japan Society of Civil Engineers,1999, p. 77.

(12) Bui, V. K., Montgomery, D., Hinczak, I. y Turner, K.: "Rapid testing method for segregation resistance of self-compacting concrete", Cem. Concr. Res., vol. 32, no 9 (2002), pp. 1489-1496.

(13) Petrou, M. F., Harries, K. A., Gadala-Maria, F. y Kolli, V. G.: "A unique experimental method for monitoring aggregate settlement in concrete", Cem. Concr. Res., vol. 30, no 5 (2000), pp. 809-816.

(14) Safawi, M. I., Iwaki, I. y Miura, T.: "The segregation tendency in the vibration of high fluidity concrete", Cem. Concr. Res., vol. 34, n० 2 (2004), pp. 219-226.

(15) Bilgil, A., Ozturk, B. y Bilgil, H.: "A numerical approach to determine viscosity-dependent segregation in fresh concrete", Applied Mathematics and Computation, vol. 162, no 1 (2005), pp. 225-245.

(16) Assaad, J., Khayat, K. H. y Daczko, J.: "Evaluation of static stability of self-consolidating concrete", ACI Materials Journal, vol. 101, no 3 (2004), pp. 207-215.

(17) Rols, S., Ambroise, J. y Péra, J.: "Effects of different viscosity agents on the properties of self-levelling concrete", Cem. Concr. Res., vol. 29, no 2 (1999), pp. 261-266.

(18) Rooney, M. J. y Bartos, P. J. M.: "Development of the settlement column segregation test for fresh self-compacting concrete", Proceedings of $2^{\text {nd }}$ international RILEM symposium on self-compacting concrete, Tokyo, 2001, pp. 109-116.

(19) Khayat, K. H., Manai, K. y Trudel, A.: "In situ mechanical properties of wall elements cast using self-consolidating concrete", $A C I$ Materials Journal, vol. 94, no 6 (1997), pp. 491-500.

(20) Khayat, K. H., Tremblay, S. y Paultre, P.: "Structural response of self-consolidating concrete columns", Proceedings of $1^{\text {st }}$ international RILEM symposium on self-compacting concrete, Stockholm, 1999, pp. 291-306.

(21) Zhu, W., Gibbs, J. C. y Bartos, P. J.: "Uniformity of in situ properties of self-compacting concrete in full-scale structural elements", Cement and Concrete Composites, vol. 23, no 1 (2001), pp. 57-64.

(22) Hoffmann, C. y Leemann, A.: "Homogeneity of structures made with self-compacting concrete and conventional concrete", Proceedings of $3^{\text {rd }}$ international RILEM symposium on self-compacting concrete, Reykjavik, 2003, pp. 619-627.

(23) Khayat, K. H. y Guizani, Z.: "Use of viscosity-modifying admixture to enhance stability of fluid concrete", ACI Materials Journal, vol. 94, no 3 (1997), pp. 332-340.

(24) Sedran, T.: Rhéologie et rhéometrie des bétons. Application aux bétons autonivelants. Tesis doctoral, École Nationale des Ponts et Chaussées, París, 1999, p. 219.

(25) Gibbs, J. C. y Zhu, W.: "Strength of hardened self compacting concrete", Proceedings of 1st international RILEM symposium on self compacting concrete, Stockholm, 1999, pp. 199-209. 
(26) Gettu, R., Gomes, P. C. y Agulló, L.: "Diseño de hormigones autocompactables de alta resistencia. Dosificación y métodos de caracterización", Proceedings II congreso de ACHE, Madrid, 2002, pp. 13-22.

(27) Aïtcin, P.C.: High Performance Concrete, E\&FN Spoon (ed.), Londres, 1999.

(28) Valcuende, M. O., Parra, C. y Benlloch, J.: "Permeabilidad, porosidad y resistencia a compresión de los hormigones autocompactables", Mater. Construcc., vol. 55, no 280 (2005), pp. 5-14. 